\begin{tabular}{|c|c|c|}
\hline & Int.J.Curr.Microbiol.App.Sci (2021) 10(12): 190-197 & \\
\hline & $\begin{array}{l}\text { International Journal of Current Microbiology and Applied Sciences } \\
\text { ISSN: 2319-7706 Volume } 10 \text { Number } \mathbf{1 2} \mathbf{( 2 0 2 1 )} \\
\text { Journal homepage: http://www.ijcmas.com }\end{array}$ & $\$ 0$ \\
\hline $\begin{array}{l}\text { EXCELLENT } \\
\text { PUBLISHERS }\end{array}$ & & \\
\hline
\end{tabular}

Original Research Article https://doi.org/10.20546/ijcmas.2021.1012.022

\title{
Assessment of Nutrient Intake of Pre-School (4-5 Years) Tribal Girls of Udaipur District, India
}

\author{
Noopur Auddy* and Vishakha Singh \\ Department of Foods and Nutrition, College of Community and Applied Sciences, Maharana \\ Pratap University of Agriculture and Technologies, Udaipur, Rajasthan, India \\ *Corresponding author
}

\section{Keywords}

Preschool children, RDA, Mean nutrient intake, mean food intake

\section{Article Info}

Received: 11 November 2021 Accepted: 06 December 2021 Available Online: 10 December 2021

\section{A B S T R A C T}

Malnutrition is by far the highest contributor to child mortality, present in half of all the cases globally. Malnutrition is more common in India than in Sub-Saharan Africa. One in every three malnourished children in the world lives in India. The nutritional status of an individual is often the result of many interrelated factors. The main objectives include to study the dietary intake of 4-5 years old tribal girls. To study the dietary adequacy of 4-5 years old tribal girls. Purposive sampling was adopted for this study. In this study, a total of 224 pre-school girls of 4-5 year old were selected from Kotra and Jhadol block of Udaipur who were already enrolled in any nutritional program (like Anganwadi or Balwadi centers). They were interviewed through the 24hourrecall method of diet survey to assess the food and nutrient intake to assess the dietary adequacy. The present study shows that the gap between the mean intake and the Recommended Dietary Allowances (RDA) value for nutrients like energy (682.84 $\mathrm{kcal} / \mathrm{d}$ in Kotra and $585.18 \mathrm{kcal} / \mathrm{d}$ in Jhadol), calcium $(117.12 \mathrm{mg} / \mathrm{d}$ in Kotra and $114.06 \mathrm{mg} / \mathrm{d}$ in Jhadol), iron (6.30 mg/d in Kotra and $5.15 \mathrm{mg} / \mathrm{d}$ in Jhadol), zinc (3.12 $\mathrm{mg} / \mathrm{d}$ in Kotra and $2.34 \mathrm{mg} / \mathrm{d}$ in Jhadol), Ascorbic Acid $(6.78 \mathrm{mg} / \mathrm{d}$ in Kotra and 5.40 $\mathrm{mg} / \mathrm{d}$ in Jhadol), $\beta$-carotene $(2.99 \mu \mathrm{g} / \mathrm{d}$ in Kotra and $1.41 \mu \mathrm{g} / \mathrm{d}$ in Jhadol), and retinol $(4.21 \mu \mathrm{g} / \mathrm{d}$ in Kotra and $1.87 \mu \mathrm{g} / \mathrm{d}$ in Jhadol) were inadequate while their diets were found secured regarding protein intake $(20.36 \mathrm{~g} / \mathrm{d}$ in Kotra and $16.98 \mathrm{~g} / \mathrm{d}$ in Jhadol). The diet of tribal 4-5 year girls was found exceptionally inadequate in protective foods like green leafy vegetables, roots and tubers, energy giving foods like fats and body building foods like milk and milk products.

\section{Introduction}

Malnutrition affects everywhere around the world and both the developed and developing countries are suffering from malnourishment.
The effect of malnutrition remains and brings devastation to the individual's community and ultimately the nation's standard of living. Malnutrition among under-five children is a major public health problem in India. The 
children pre-school age (4-5 years) is an important stage of life where nutrition plays an important role and has long-lasting effects in the later years of life. Malnutrition in preschool children has significant, long-term consequences since it inhibits motor, sensory, cognitive, social and emotional development. Approximately, $70 \%$ of the world's malnourished children live in Asia, resulting in the region's highest attentiveness of childhood malnutrition. The mortality rate of children $<5$ years of age in India contributes to $22 \%$ of the world mortality rates. The NFHS-4 data of 2015-16 shows that $38 \%$ of children below five years are stunted (low height for age); $21 \%$ are wasted (low weight for height); $36 \%$ are underweight (low weight for age); whereas in Rajasthan $23 \%$ of children under-5 years of age were wasted, $39.1 \%$ were stunted and $36.7 \%$ were underweight and $36.7 \%$ of the children under-5 were severely wasted. Whereas in Rajasthan Infant Mortality Rate (IMR) is $35.4 \%$ (NFHS-4, 2016).

India is a land of copious traditions and people. Many different ethnic groups found here outnumber many countries. With more than 84.4 million, India has the largest population of tribal people in the world (Das and Bose, 2012). The southern zone of Rajasthan includes the districts of Banswara, Dungarpur, and Udaipur in which $43.80 \%$ of the total tribal population of Rajasthan is settled. Bheel, Meena, Garasia and Damor are the tribes that are found in this zone. The tribal population of Udaipur is highly exposed to incidences of child malnutrition. According to the Child Fund (India), one of the world's largest voluntary organizations working on child development, many children in the 0-6yearage group in south Rajasthan's tribal belt (comprising the six districts of Udaipur, Banswara, Pratapnagar, Chittorgarh, Rajsamand and Dungarpur) are Vitamin A deficient; $60-70 \%$ of them suffer from malnutrition. These tribal people are the poorest, mostly depends on hunting, agriculture and fishing for their livelihood, and hence they are at higher risk of under nutrition. National Nutritional Monitoring Bureau (NNMB) had surveyed 'Diet and nutritional status of the tribal population during 2007-08, as a second repeat survey in nine States of India to study changes in the diet and nutritional status of the tribal population residing in the Integrated Tribal Development Agency (ITDA) Areas. ITDA operates in areas where the tribal population is more than $50 \%$ in that particular area. Is shows that the proportion of tribals of different age groups consuming less than $70 \%$ of protein and energy was observed to be higher compared to their rural counterparts. Only about $29-32 \%$ of children of different age groups were consuming diets that were adequate in both protein and energy.

The main objectives include to study the dietary intake of 4-5 years old tribal girls. And also to study the dietary adequacy of 4-5 years old tribal girls.

\section{Materials and Methods}

A community based purposive study was carried out in the Jhadol and Kotra tribal block of the Udaipur district of Rajasthan. In this study, a total of 224 pre-school tribal girls of 4-5 year old were selected from both blocks of Udaipur who were already enrolled in any nutritional program (like Anganwadi or Balwadi centers). The diet survey was carried out by using the 24-hour dietary recall method. The one-day meal was calculated for its portion size and nutritive value that is carbohydrate, protein, energy, fat, iron, vitamin $C, \beta$-carotene, and zinc with the help of the Indian Food Composition (IFC) table 2017. The obtained value was compared to a balanced diet for age and Recommended Dietary Allowances (RDA), 2020. 


\section{Results and Discussion}

The result obtained from the present investigation as well as the relevant discussion has been submitted under the following heads:

Coverage particulars and sociodemographic profile of study subjects

A total of 224 tribal girl children were covered, of which $55.36 \%$ were 4 years and $44.64 \%$ were five years of age. The majority of the caste of the children were Hindu. Majority of the children, $96.43 \%$ were from nuclear family and $3.57 \%$ belonged to the joint family. Size of the family is a significant factor of determining mouth to feed and earning members; $80.80 \%$ of the children were from a small family that is maximum of four members, $14.73 \%$ children were from a medium family that is maximum of five to seven members and $0.89 \%$ children were from a large family that is having more than seven members. The average family size was 3.86 $( \pm 0.92)$. About $41 \%$ of fathers and $39 \%$ of mothers of the children were illiterate. About $42.86 \%$ of fathers and $66.52 \%$ of mothers had agriculture as an occupation and $55.36 \%$ of fathers and $6.7 \%$ of mothers were doing labour work. (Table 1).

\section{Food and nutrient intake among children}

Food consumed by pre-school tribal girls (4-5 years) was calculated using the 24-hour recall method for one day. Food intake of the children was affected by seasonal variations like consumption of maize and pulses was higher during the period of data collection i.e. March to June. The intake of all the food items was higher in the Kotra block except the intake of milk and milk products which was higher in the Jhadol block. Intakes of food among tribal girls' families were mainly influenced by their socio-economic status which was very poor.
The mean intake of cereals in the Jhadol block was $83.20 \mathrm{~g} / \mathrm{d}$ while in the Kotra block the mean intake was $110.11 \mathrm{~g} / \mathrm{d}$ as indicated in Table 2. Among cereals, maize was consumed by the majority of tribal girl's families due to good production in these areas. Pulses are consumed daily due to higher production in these areas. Mean intake of pulses by the girls of Jhadol was $33.13 \mathrm{~g} / \mathrm{d}$ and Kotra the mean intake was $37.60 \mathrm{~g} / \mathrm{d}$. The mean intake of milk and milk products was less in their diet i.e. $9.04 \mathrm{~g} / \mathrm{d}$ in Kotra and $12.45 \mathrm{~g} / \mathrm{d}$ in Jhadol. However, the availability of low GLVs OVs and roots and tubers was high in both Kotra and Jhadol but the mean intake of all type of vegetables was their daily diet found to be almost negligible in due to their disliking of leafy vegetables which was the mean GLV intake $0.87 \mathrm{~g} / \mathrm{d}$ in Kotra and $0.29 \mathrm{~g} / \mathrm{d}$ in Jhadol, mean intake of root vegetables was $2.83 \mathrm{~g} / \mathrm{d}$ in Jhadol and $5.63 \mathrm{~g} / \mathrm{d}$ in Kotra and mean intake of other vegetables was $10.83 \mathrm{~g} / \mathrm{d}$ in Jhadol and $15.58 \mathrm{~g} / \mathrm{d}$ in Kotra. The intake of fruits was very much low in both blocks. Very few families of girl reported intake of fruits during the study. Table 2 reveals that the mean intake of fruits in Jhadol was $0.29 \mathrm{~g} / \mathrm{d}$ while in Kotra it was $0.72 \mathrm{~g} / \mathrm{d}$. The mean intake of visible fats in plate of Jhadol was $6.17 \mathrm{~g} / \mathrm{d}$ and in Kotra the mean intake was $8.14 \mathrm{~g} / \mathrm{d}$. The intake of sugar was high in both blocks, in Jhadol the mean intake of sugar was $24.33 \mathrm{~g} / \mathrm{d}$ and the mean intake of sugar was $16.38 \mathrm{~g} / \mathrm{d}$ in Kotra.

\section{Mean Nutrient Intake of the Pre-school tribal girl 4-5 years' children: Mean Nutrient}

The intake of 224 pre-school tribal girls (4-5 years) was calculated by using the Indian Food Composition (IFC) table 2017 and compare with Recommended Dietary allowance, 2020 (RDA). Intake of 10 nutrients which include protein, fat, carbohydrate, energy, calcium, iron, $\beta$-carotene, Retinol, Vitamin $\mathrm{C}$ and Zinc. 


\section{Protein}

Data in Table 3 indicates that in Jhadol the mean protein intake was $16.98 \mathrm{~g}$ and in Kotra, it was $20.36 \mathrm{~g}$. In both the block, the intake was approximately equal to the RDA value because of the high production and consumption of pulses crops in these blocks.

\section{Fat}

As stated in the consumption pattern of fats and oils most of the tribal families do not include fats and oils daily. The intake was lower than the recommended values i.e. $17.82 \mathrm{~g}$ in Jhadol and $16.99 \mathrm{~g}$ in Kotra as indicated in Table 3. Bhils are mainly maize eaters and the content of fat in maize is higher than wheat flour, they prefer goat milk which also contains a slightly higher amount of fat than cow's milk and also the recommended dietary intake includes visible fat while the above values are a combination of both visible and invisible fat (Joshi, 2013). There was no significant difference in the intake of fat in both blocks.

\section{Carbohydrate}

The mean value of carbohydrate in the diets of surveyed pre-school girl children 4-5-year-old of age was $102.98 \mathrm{~g}$ in Jhadol and 117.13g in Kotra. There was no significant difference between the values of carbohydrates in both blocks which are depicted in Table 3 .

\section{Energy}

The mean value of energy for Jhadol tribal girls was $585.18 \mathrm{kcal}$ and $682.84 \mathrm{kcal}$ for the tribal girls of Kotra which was less than the recommended value. Table 3 depicts that there was no significant difference between the values of energy for both blocks.

\section{Calcium}

Among the five major food groups milk and milk products form a major source of calcium in the diet and tribal families mainly consume goat milk and buttermilk which contain a very less amount of calcium as compared to the calcium content of cow and buffalo milk (Joshi, 2013). The mean value for calcium intake in the Kotra block was higher i.e.117.12 $\mathrm{mg}$ whereas Jhadol was $114.06 \mathrm{mg}$. The intake of calcium was found lower than the recommended value in both blocks. There was a significant difference in the values of calcium for both the block.

\section{Iron}

Perusal of Table 3 depicts that the mean iron intake by tribal girls of Jhadol and Girwa block was almost the same i.e. $5.15 \mathrm{~g}$ and $6.30 \mathrm{~g}$ respectively. The values are lower than the recommended allowances. Even due to the availability of green leafy vegetables and jaggery the values are lower because other food items consumed by tribal girls are not good sources of iron like maize flour contain half the amount of iron than wheat flour (Joshi, 2013). There was no significant difference between the values of iron intake in both blocks.

\section{Retinol \& $\beta$-Carotene}

The mean value of carotene and retinol intake in both the blocks was much lower than the recommended value i.e. $1.41 \mu \mathrm{g} \beta$-carotene and $1.87 \mu \mathrm{g}$ Retinol in Jhadol and $2.99 \mu \mathrm{g} \beta$ carotene and $4.21 \mu \mathrm{g}$ Retinol in Kotra. Only a rich source of carotene included by tribal families in their diets is maize. Other sources like goat milk have a low amount of carotene. There was a significant difference between the values of carotene intake in both blocks. 
Table.1 Household socio-demographic characteristics of study subjects

\begin{tabular}{|c|c|c|c|}
\hline S.No. & Variable & Frequency & Percentage (\%) \\
\hline \multicolumn{4}{|c|}{ Child Age (years) } \\
\hline & 4 & 124 & 55.36 \\
\hline & 5 & 100 & 44.64 \\
\hline \multirow[t]{3}{*}{2} & \multicolumn{3}{|c|}{ Type of Family } \\
\hline & Nuclear Family & 216 & 96.43 \\
\hline & Joint Family & 8 & 3.57 \\
\hline \multirow[t]{4}{*}{3} & \multicolumn{3}{|c|}{ Family Size } \\
\hline & Small family & 181 & 80.80 \\
\hline & Medium family & 33 & 14.73 \\
\hline & Large Family & 2 & 0.89 \\
\hline \multirow[t]{2}{*}{4} & \multicolumn{3}{|c|}{ Caste } \\
\hline & Scheduled Tribe & 224 & 100 \\
\hline \multirow[t]{2}{*}{5} & \multicolumn{3}{|c|}{ Religion } \\
\hline & Hindu & 224 & 100 \\
\hline \multirow[t]{8}{*}{6} & \multicolumn{3}{|c|}{ Mother Education } \\
\hline & Illiterate & 148 & 66.07 \\
\hline & literate & 39 & 17.41 \\
\hline & Primary & 14 & 6.25 \\
\hline & Middle Edu. & 15 & 6.70 \\
\hline & Secondary & 3 & 1.34 \\
\hline & Sr. Secondary & 2 & 0.89 \\
\hline & Graduate & 3 & 1.34 \\
\hline \multirow[t]{8}{*}{7} & \multicolumn{3}{|c|}{ Father Education } \\
\hline & Illiterate & 86 & 38.39 \\
\hline & literate & 41 & 18.30 \\
\hline & Primary & 37 & 16.52 \\
\hline & Middle Edu. & 31 & 13.84 \\
\hline & Secondary & 20 & 8.93 \\
\hline & Sr. Secondary & 6 & 2.68 \\
\hline & Graduate & 3 & 1.34 \\
\hline \multirow[t]{4}{*}{8} & \multicolumn{3}{|c|}{ Father Occupation } \\
\hline & Agriculture & 96 & 42.86 \\
\hline & Labour & 124 & 55.36 \\
\hline & Other & 4 & 1.79 \\
\hline \multirow[t]{5}{*}{9} & \multicolumn{3}{|c|}{ Mother Occupation } \\
\hline & Agriculture & 149 & 66.52 \\
\hline & Labour & 15 & 6.70 \\
\hline & Housewife & 55 & 24.55 \\
\hline & Other & 5 & 2.23 \\
\hline
\end{tabular}


Table.2 Pre-school girl children (4-5 years) food intake Jhadol and Kotra block

\begin{tabular}{|c|c|c|c|c|c|c|c|}
\hline \multirow{2}{*}{ Food Groups } & \multicolumn{7}{|c|}{ Age group - 4-5 years } \\
\cline { 2 - 8 } & \multirow{2}{*}{ RDI } & \multicolumn{3}{|c|}{ Jhadol } & \multicolumn{3}{c|}{ Kotra } \\
\cline { 3 - 8 } & & Mean & SD & SE & Mean & SD & SE \\
\hline Cereals (gm) & 60 & 83.2 & 35.59 & 3.25 & 110.11 & 37.35 & 3.66 \\
\hline Pulses (gm) & 30 & 33.13 & 12.69 & 1.16 & 37.6 & 16.74 & 1.64 \\
\hline GLV (gm) & 50 & 0.29 & 2.27 & 0.21 & 0.87 & 5.59 & 0.55 \\
\hline Fats \& oil (gm) & 25 & 6.17 & 3.6 & 0.33 & 8.14 & 3.11 & 0.31 \\
\hline Fruits (gm) & 100 & 0.29 & 1.34 & 0.12 & 0.72 & 3.37 & 0.33 \\
\hline $\begin{array}{c}\text { Milk \& Milk products } \\
\text { (ml) }\end{array}$ & 500 & 12.45 & 7.71 & 0.7 & 9.04 & 12.27 & 1.2 \\
\hline other vegetable (gm) & 50 & 10.45 & 11.62 & 1.06 & 15.58 & 15.06 & 1.48 \\
\hline Roots and Tubers (gm) & 50 & 2.83 & 7.24 & 0.66 & 5.63 & 10.83 & 1.06 \\
\hline Sugar (gm) & 15 & 24.33 & 12.43 & 1.13 & 16.38 & 11.86 & 1.16 \\
\hline
\end{tabular}

Table.3 Pre-school girl children (4-5 years) mean Nutrient intake Jhadol and Kotra block

\begin{tabular}{|c|c|c|c|c|c|c|c|}
\hline \multirow{2}{*}{ Nutrient } & \multicolumn{7}{|c|}{ Age group - 4-5 years } \\
\cline { 2 - 8 } & RDA & \multicolumn{3}{|c|}{ Jhadol } & \multicolumn{3}{c|}{ Kotra } \\
\cline { 3 - 8 } & & Mean & SD & SE & Mean & SD & SE \\
\hline Energy (k.cal) & 1360 & 585.18 & 161.69 & 14.76 & 682.84 & 138.46 & 13.58 \\
\hline Protein (gm) & 15.9 & 16.98 & 4.66 & 0.43 & 20.36 & 5.19 & 0.51 \\
\hline Fat (gm) & 25 & 16.99 & 8.75 & 0.8 & 17.82 & 7.74 & 0.76 \\
\hline Carbohydrate (gm) & 130 & 102.98 & 51.03 & 4.66 & 117.13 & 51.52 & 5.05 \\
\hline Calcium (mg) & 450 & 114.06 & 41.94 & 3.83 & 117.12 & 99.66 & 9.77 \\
\hline Iron (mg) & 11 & 5.15 & 1.48 & 0.14 & 6.30 & 1.68 & 0.16 \\
\hline Vitamin A( $(\mathbf{g})$ & 510 & 1.41 & 7.97 & 0.73 & 2.99 & 12.16 & 1.19 \\
\hline & 400 & 1.87 & 6.12 & 0.56 & 4.21 & 9.29 & 0.91 \\
\hline Ascorbic acid (mg) & 32 & 5.40 & 4.28 & 0.39 & 6.78 & 4.88 & 0.48 \\
\hline Zinc (mg) & 4.5 & 2.34 & 1.81 & 0.16 & 3.12 & 1.67 & 0.16 \\
\hline
\end{tabular}

\section{Vitamin-C}

Mean value for the intake of Vitamin-C by tribal girls of Jhadol and Kotra block was lower than the recommended value.

Whereas the availability of Bathua, green chillies, coriander, tomato, cabbage, radish leaves, and Ziziphus in an area that is a good source of Vitamin-C (Joshi, 2013). Data in Table 3 indicates that in the Jhadol block the mean intake was $5.40 \mathrm{mg}$ and $6.78 \mathrm{mg}$ in the
Kotra block. There was no significant difference in the values of the mean intake of Vitamin-C in both blocks.

\section{Zinc}

In Jhadol the mean intake of zinc was $2.34 \mathrm{mg}$ and in Kotra, it was $3.12 \mathrm{mg}$. Maize, chillies, onion, potato, Ziziphus, fresh dates are good sources of zinc which are included by tribals in their diets (Joshi, 2013). There was no significant difference in the values of zinc 
intake in both blocks which are depicted in Table 3.

Consumption of food for tribal girls (4-5 years) is a means of satisfying hunger, the appetite of the stomach. Consumption of cereals, pulses, and sugar was high in both blocks. Among cereals tribals, girls mostly consume maize and wheat. Rice is not cultivated in both areas thus consumed less. Among green leafy vegetables, availability is high in these blocks but consumption was low by the majority of the tribal girls in both blocks. Tribals consume a high amount of sugar in tea. The consumption of milk and milk products was higher in the Kotra block. While the consumption of root vegetables, other vegetables, fats and oils, and fruits were low in both the blocks. Due to low purchasing power, tribal families are unable to include these foodstuffs daily in their diet especially fats and oils. The Consumption of pulses was higher in both blocks due to the local production of pulses crops in these blocks.

Regarding nutrient intake diets of pre-school tribal girls (4-5 years) were found adequate in protein, fat, and carbohydrate $(\mathrm{CHO})$, in Inspite of adequate intake of pulses, cereals especially maize, their protein requirements are fulfilled during the one-day recall method. Regarding fat tribals are mainly maize eaters and the content of fat in maize is higher than wheat flour, they prefer goat milk which also contains a slightly higher amount of fat than cow's milk and also the recommended dietary intake includes visible fat while the above values are a combination of both visible and invisible fat.

Less Inclusion of Bathua, green chillies, coriander, tomato, cabbage, radish leaves, and Ziziphus in their diets contributes less amount of Vitamin-C and maize, chillies, onion, potato, Ziziphus, fresh dates are good sources of zinc which are less included by tribal girls in their diets whereas the high availability of these in both blocks. The diet of tribal girls was found less adequate in energy, calcium, iron, carotene, and retinol. Despite less consumption of milk and milk products because tribal families mainly include goat milk and buttermilk which contain a very less amount of calcium as compared to the calcium content of cow and buffalo milk. Tribals are mainly maize eaters and the amount of iron in maize is approximately half the amount present in wheat and their diets did not contain any rich source of iron. Due to the very rear consumption of fruits and non-vegetarian food daily the carotene and retinol content in their diet were less, the only source included by them is maize.

\section{References}

Das, S. and Bose, K. (2012). Nutritional deprivation among Indian tribals: A cause for concern. Anthropological Notebooks. 18 (2): 5-16.

Joshi, S. 2013. Food Consumption Pattern and Dietary Adequacy Among Bhils of Udaipur (Rajasthan). International Journal of Science and Research (IJSR) ISSN (Online): 2319-7064.

Nutrition in India, NFHS - 4, MOHFW, Government of India, 2015-16. (http://rchiips.org/NFHS/factsheet_NFHS4.shtml) Retrieved on $9^{\text {th }}$ February 2020

National Institute of Nutrition (NIN). Nutrient requirements and recommended dietary allowances for Indians. Indian Council of Medical Research (ICMR), 2010.

National Nutrition Monitoring Bureau. Diet and Nutritional status of tribal populationReport on first repeat survey, NNMB Technical Report No. 25. Hyderabad: National Institute of Nutrition, Indian Council of Medical Research; 2009.

UN: global child deaths. [Cited in 2020 Feb 9]. Available from http://www.who.int/mediacentre/news/rele ases/2013/child_mortality_causes_201309 13/en/index.html 


\section{How to cite this article:}

Noopur Auddy and Vishakha Singh. 2021. Assessment of Nutrient Intake of Pre-School (4-5 Years) Tribal Girls of Udaipur District. Int.J.Curr.Microbiol.App.Sci. 10(12): 190-197. doi: https://doi.org/10.20546/ijcmas.2021.1012.022 